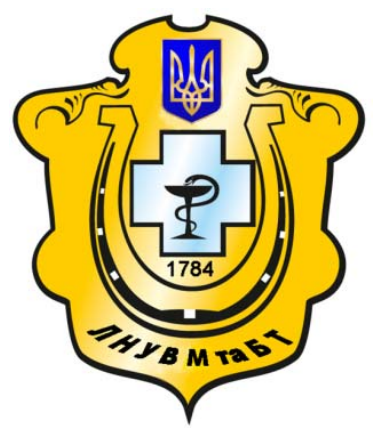

Науковий вісник Львівського національного університету ветеринарної медицини та біотехнологій імені С.3. Гжицького

Scientific Messenger of Lviv National University of Veterinary Medicine and Biotechnologies named after S.Z. Gzhytskyj

doi:10.15421/nvlvet7339

ISSN 2518-7554 print

ISSN 2518-1327 online

$\underline{\text { http://nvlvet.com.ua/ }}$

УДК 619:616:37.638.7

\title{
Мікроскопічна будова та морфометричні показники підшлункової залози собак в постнатальному періоді онтогенезу
}

\author{
Л.П. Горальський ${ }^{1}$, І.М. Сокульський ${ }^{1}$, Н.В. Демус ${ }^{2}$, З.Д. Зорич ${ }^{3}$ \\ Sokulskiy_1979@ukr.net \\ ${ }^{1}$ Житомирський національний агроекологічний університет, \\ вул. Корольова, 39, м. Житомир, 10025, Україна; \\ ${ }^{2}$ Львівський національний університет ветеринарної медицини та біотехнологій імені С.3. Гюсицького, \\ вул. Пекарська, 50, м. Львів, 79010, Україна; \\ ${ }^{3}$ Белградський університет, м. Белград, 11000, Сербія
}

\begin{abstract}
У роботі на основі анатомічних, гістологічних, морфметричних та статистичних методів досліджень з'ясовано гістоморфологію підшлункової залози клінічно здорових собак у постнатальному періоді онтогенезу. З'ясовано, щңо у процесі росту і розвитку тварин абсолютна маса (АМ) підшлункової залози збільшується з 1,44 \pm 0,64 г у иуценят добового віку до

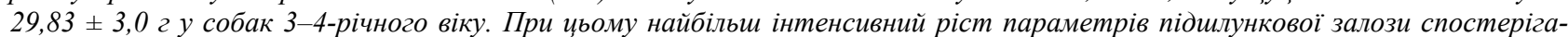
ється до 8-місячного віку. Відносна маса органа з віком, навпаки, зменшується. Гістоструктура підшлункової залози складається з окремих часточок, до складу яких входять екзокринна та ендокринна частини. Екзокринна частина підилункової залози згідно з проведеними морфометричними дослідженнями займає основну масу паренхіми органа - площча ї̈ у новонароджених иуценят складає 99,49 \pm 0,04\%. 3 віком екзокринна частина паренхіми залози зменшується $і$ у статевозрілих собак дорівнює 98,55 40,07\%. Структурною одиницею екзокринної частини є округлої або овальної форми панкреатичні ацинуси, стінка яких побудована із панкреатоцитів. Останні мають витягнуту або призматичну форму $і$ чітко виражену полярну диференціачію - базальну та апікальну зони. Об'єм панкреаточитів з віком тварин зростає з 353,33 $\pm 12,91$ мкм ${ }^{3}$ у однодобових иуиенят до 507,84 \pm 25,06 мкм у у 3-4-річних собак, щчо призводить до зміни ядерно-цитоплазматичного відно-

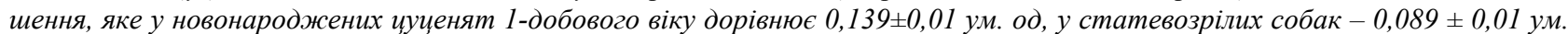
од, відповідно зменшуючись ( $P<0,001)$ у 1,56 раза, і свідчить про морфофункиіональну активність панкреатоиитів.

Ендокринна частина підилункової залози займає відповідно незначну площу: у 1-добових иуиенят становить 0,51 \pm 0,04\%, у собак 3-4-річного віку - 1,45 \pm 0,07\%. Вона представлена незначним скупченням клітин округлої або овальної форми, які утворюють панкреатичні острівиі (острівиі Лангерганса), діаметр яких у иуценят однодобового віку складає $35,31 \pm 0,39$ мкм, у статевозрілих собак-36,65 $\pm 0,13$ мкм.

Ключові слова: мікроскопічна будова, гістоструктура органа, гістоморфологія, підилунковий сік, морфометричні показники підилункової залози, статевозріла собака, перегородки, часточки, ацинуси, острівці Лангерганса, ядерноичтоолазматичне віднотення.
\end{abstract}

\section{Микроскопическое строение и морфометрические показатели поджелудочной железы собак в постнатальном периоде онтогенеза}

\author{
Л.П. Горальский, И.Н. Сокульский, Н.В. Демус, З.Д. Зорич \\ Sokulskiy_1979@ukr.net
}

\author{
${ }^{I}$ Житомирский национальный агроэкологический университет, \\ ул. Королева, 39, г. Житомир, 10025, Украина; \\ ${ }^{2}$ Львовский нацииональный университет ветеринарной медицины и биотехнологий имени С.3. Гжицякого,
}

Citation:

Horalskyi, L.P., Sokulskyi, I.M., Demus, N.V., Zoric, Z.D. (2017). Microscopic structure and morphometric parameters pancreatic dogs in postnatal ontogenesis. Scientific Messenger LNUVMBT named after S.Z. Gzhytskyj, 19(73), 187-192. 
ул. Пекарская, 50, г. Львов, 79010, Украина;

${ }^{3}$ Белградский университет, г. Белград, 11000, Сербия

В работе на основе анатомических, гистологических, морфометрических и статистических методов исследований установлено гистоморфологию поджелудочной железы клинически здоровых собак в постнатальном периоде онтогенеза.

Установлено, что в процессе роста и развития животных абсолютная масса (АМ) поджелудочной железы увеличивается с 1,44 \pm 0,64 г у щзенков суточного возраста до 29,83 \pm 3,0 г у собак 3-4-летнего возраста. При этом наиболее интенсивный рост параметров поджелудочной железы наблюдается до 8-месячного возраста. Относительная масса органа с возрастом, наоборот, уменьшается. Гистоструктура поджелудочной железы состоит из отдельных долек, в состав которых входят экзокринная и эндокринная часть. Экзокринная часть поджелудочной железы согласно проведенных морфометрических исследований занимает основную массу паренхимы органа - площадь ее у новорожденных щенков составляет 99,49 \pm 0,04\%. С возрастом экзокриннаяа часть паренхимы железы уменьшается и в половозрельх собак равна 98,55 \pm 0,07\%. Структурной единицей экзокринной части является округлой или овальной формы панкреатические ацинуcbl, стенка которых построена из панкреаточитов. Последние имеют вытянутую или призматическую форму и четко выраженную полярную дифференциацию - базальную и апикальную зонь. Объем панкреатоцитов с возрастом животньх

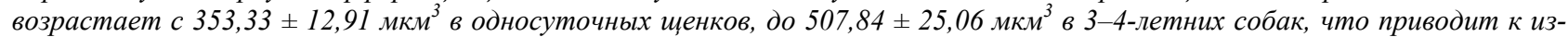
менению ядерно-цитоплазматического отношения, которое у новорожденных щенков 1-суточного возраста равно 0,139 \pm 0,01 усл. ед, в половозрельх собак - 0,089 \pm 0,01 усл. ед, соответственно уменьшаясь (P < 0,001) в 1,56 раза, и свидетельствует о морфофункииональной активности панкреатоцитов.

Эндокринная часть поджелудочной железы занимает соответственно незначительную площадь: в 1-суточньх щенков составляет 0,51 \pm 0,04\%, у собак 3-4-летнего возраста - 1,45 \pm 0,07\%. Она представлена незначительным скоплением клеток округлой или овальной формы, которые образуют панкреатические островки (островки Лангерганса), диаметр которых у шенков односуточного возраста составляет 35,31 \pm 0,39 мкм, у половозрельх собак - 36,65 \pm 0,13 мкм.

Ключевые слова: микроскопическое строение, гистоструктура органа, гистоморфология, поджелудочный сок, морфометрические показатели поджелудочной железы, половозрелая собака, перегородки, дольки, ацинусы, островки Лангерганса, ядерно-цичтоплазматическое отночение.

\title{
Microscopic structure and morphometric parameters pancreatic dogs in postnatal ontogenesis
}

\author{
L.P. Horalskyi ${ }^{1}$, I.M. Sokulskyi ${ }^{1}$, N.V. Demus ${ }^{2}$, Z.D. Zoric ${ }^{3}$ \\ Sokulskiy_1979@ukr.net

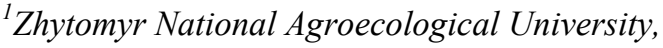 \\ Korolova Str., 39, Zhytomyr, 10025, Ukraine; \\ ${ }^{2}$ Lviv national university of veterinary medicine and biotechnologies named after S. Gzhytskyj, \\ Pekarska Str., 50, Lviv, 79010, Ukraine; \\ ${ }^{3}$ University of Belgrade, Belgrade, 11000, Serbia
}

The work on the basis of anatomical, histological, morfmetric and statistical research methods found histomorphology of pancreas in clinically healthy dogs at a postnatal ontogenesis.

It was found that in the process of growth and development of animals sheer mass (AM) of the pancreas increased from $1.44 \pm$ $0.64 \mathrm{~g}$ daily puppies to age $29.83 \pm 3.0 \mathrm{~g}$ dogs 3-4 years of age. The most intensive growth options of pancreas observed to 8 months of age. Relative body weight with age, on the contrary, decreases.

Histological structure of pancreas consists of individual particles composed of exocrine and endocrine parts. Exocrine part of the pancreas by morphometric studies conducted occupies the bulk of the parenchyma of the organ - the area of neonatal puppies is $99.49 \pm 0.04 \%$. From the age of exocrine gland parenchyma decreases in mature dogs is $98.55 \pm 0.07 \%$.

The structural unit of the exocrine part is round or oval pancreatic acini, which built a wall pancreatocytes. The latter are elongated or prismatic shape and distinct polar differentiation - basal and apical zones. Pancreatocytes volume increases with age animals from $353.33 \pm 12.91 \mathrm{mkm}^{3}$ in one day puppies to $507.84 \pm 25.06 \mathrm{mkm}^{3}$ 3-4-year-old dog, which leads to changes in the nuclear-cytoplasmic ratio, which in newborn puppies 1-day of age is $0.139 \pm 0.01$ conv. units in mature dogs $-0.089 \pm 0.01$ conv. units, respectively, decreasing to $(P<0.001) 1.56$ times, and shows Morphofunctional pancreatocytes activity.

Endocrine part of pancreas occupies a small area, respectively, in 1-day puppies is $0.51 \pm 0.04 \%$, in dogs 3-4 years of age $1.45 \pm 0.07 \%$. It is represented by small clusters of cells round or oval, which form pancreatic islets (islets of Langerhans) in diameter puppies one day age is $35.31 \pm 0.39 \mathrm{~mm}$. in mature dogs $-36.65 \pm 0.13 \mathrm{~mm}$.

Key words: microscopic structure, histostructure authority histomorphology, pancreatic juice, morphometric parameters pancreas, mature dog, partitions, slices, acini, islets of Langerhans, nuclear-cytoplasmic ratio.

\section{Вступ}

Підшлункова залоза є важливим органом, який забезпечує адекватний перебіг травлення, вона $є$ залозою зовнішньої і внутрішньої секреції (Horalskyi and Dubych, 2010), яка бере участь практично в усіх фiзioлогічних процесах, починаючи від травлення i до процесів адаптації, в тому числі й у підтриманні гомеостазу всього організму.

Підшлункова залоза виробляє підшлунковий сік, який по протоці надходить у дванадцятипалу кишку (ферменти для перетравлення білків) і гормони (інсулін, глюкагон) в кров, що регулюють обмін вуглеводів (Slobodian, 2008). Це - друга за величиною залоза 
травної системи зі складною трубчасто-альвеолярною будовою (Horalskyi and Dubych, 2010).

Актуальність теми. Останніми роками велика увага приділяється морфометричним дослідженням. Доведена висока ефективність морфометричної оцінки структурно-функціонального стану організму тварин на органному, тканинному та клітинному рівнях. Щорічно з'являється велика кількість монографій, наукових статей у різноманітних виданнях, що присвячені вивченню морфофункціонального стану підшлункової залози в нормі (Holzknecht et al., 1996; Akhtemiichuk and Slobodian, 2006; Horalskyi and Dubych, 2010) та при патології. У фармацевтичній промисловості з підшлункової залози тварин виробляють гормони: інсулін, ліпокаїн, ангіотрофін; отримують ферментні препарати: трипсин, хімотрипсин, хімопсин, дезоксирибонуклеазу і рибонуклеазу, еластазу, колагеназу, а також панкреатин медичний і технічний. Проте видова і вікова морфологія підшлункової залози у свійських тварин, і особливо у собак, на даний час висвітлена ще недостатньо. Саме тому вивчення гістоархітектоніки підшлункової залози клінічно здорових собак у віковому аспекті $є$ актуальним питанням ветеринарної медицини.

Метою наших досліджень було з'ясувати гістоморфологію підшлункової залози клінічно здорових собак у постнатальному періоді онтогенезу. Для досягнення цієї мети були поставлені такі завдання: з'ясувати мікроскопічну будову підшлункової залози клінічно здорових собак різних вікових груп; провести морфометричні дослідження гісто- та цитоструктур підшлункової залози клінічно здорових собак різних вікових груп.

\section{Матеріал і методи досліджень}

Дослідження виконувались на кафедрі анатомії і гістології факультету ветеринарної медицини Житомирського національного агроекологічного університету.

Об'єктом роботи була підшлункова залоза собак різновікових груп: 1-, 7-, 14-денного, 1-, 2-; 8-, $12-$ місячного віку. У роботі використовували анатомічні, гістологічні, морфометричні та статистичні методи досліджень (Horalskyi et al., 2012).

Для гістологічних та морфометричних досліджень відбирали підшлункову залозу від собак, визначали абсолютну та відносну масу, довжину та ширину часток органу. Шматочки матеріалу фіксували в 10 \%му розчині нейтрального формаліну та рідині Карнуа 3 подальшою заливкою в парафін. 3 парафінових блоків виготовляли гістологічні зрізи на санному мікротомі МС-2 завтовшки не більше 10 мкм. Для фарбування гістозрізів використовували загальноприйняті та спеціальні гістологічні методи. Для вивчення морфології клітин і тканин, морфометричних досліджень та для отримання оглядових препаратів застосовували фарбування зрізів гематоксиліном Ерліха, Караці та еозином, за методом Ван-Гізон з використанням рекомендацій, які запропоновані у посібнику Л.П. Горальського, В.Т. Хомича, О.I. Кононського (Horalskyi et al., 2012). Дослідження гістологічних препаратів здійснювали за допомогою мікроскопів «БіоламЛомо» та МБС-10. Мікрофотографування частини цих препаратів здійснювали за допомогою мікроскопа Micros MC-50 і вмонтованою у нього відеокамерою CAM V200, підключеною до персонального комп'ютера, а також мікроскопа МБС-10 із цифровою фотокамерою «Canon».

Одержані цифрові дані обробляли методом варіаційної статистики. Статистична обробка даних та оформлення результатів дослідження здійснювали за допомогою комп'ютерної програми «Excel» 3 пакету «Microsoft Office 2010».

\section{Результати та їх обговорення}

Проведеними дослідженнями встановлено, що результати органометричних досліджень підшлункової залози собак в постнатальному періоді онтогенезу показали, що абсолютна маса залози цуценят однодобового віку становить 1,44 $\pm 0,64$ г, відносна маса $0,41 \pm 0,18 \%$. Довжина органу дорівнює 8,78 $\pm 3,93$ см.

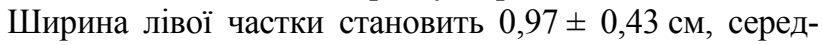
ньої - 0,88 $\pm 0,40$ см. Ширина правої частки дещо менша і дорівнює $0,65 \pm 0,29 \mathrm{~cm}$.

Підшлункова залоза складається з окремих часточок, до складу яких входять екзокринна та ендокринна частини (рис. 1).

Екзокринна частина залози займає основну масу паренхіми органу і дорівнює $449292 \pm 186,35$ мкм $^{2}$ на одиницю площі (ок. 16, об. 8) або 99,49 \pm 0,04\%. Вона побудована 3 панкреатичних ацинусів діаметром $35,31 \pm 0,39$ мкм. Вони мають витягнуту або округлу форму та відокремлюються один від одного ніжним прошарком ретикулярної тканини, в останній містяться капіляри.

Об'єм панкреацитів підшлункової залози у цуценят однодобового віку дорівнює $353,33 \pm 12,91$ мкм $^{3}$, a їхніх ядер $-36,88 \pm 0,56$ мкм $^{3}$. При цьому ядерноцитоплазматичне відношення становить $0,139 \pm$ 0,01 ум. од.

Ендокринна частина залози займає $0,51 \pm 0,04 \%$, або 2291,77 $\pm 186,35$ мкм² $^{2}$ Вона представлена незначним скупченням округлих та овальних клітин, які утворюють панкреатичні острівці, так звані острівці Лангерганса. Їх діаметр становить 61,44 \pm 4,52 мкм.

Абсолютна маса підшлункової залози у цуценят 7добового віку, порівняно з однодобовими, збільшується в 1,2 раза і становить $1,75 \pm 0,05$ г. Відносна маса залози, навпаки, зменшується і дорівнює $0,30 \pm$ 0,01\%. Параметри довжини, ширини лівої, правої та середньої часток досліджуваного органу також зменшуються і відповідно становлять $8 \pm 0,31,0,8 \pm 0,06$, $0,85 \pm 0,07$ та $0,55 \pm 0,06$ см.

Площа підшлункової залози, зайнята ендокринною паренхімою, у 7-добових цуценят становить 2326,5 \pm 240,57 мкм $^{2}$ на одиницю площі (ок. 16, об. 8), або $0,52 \pm 0,05 \%$. Основну частину підшлункової залози цуценят 7-добового віку займають ацинуси, діаметр яких дорівнює 35,15 \pm 0,41 мкм. 


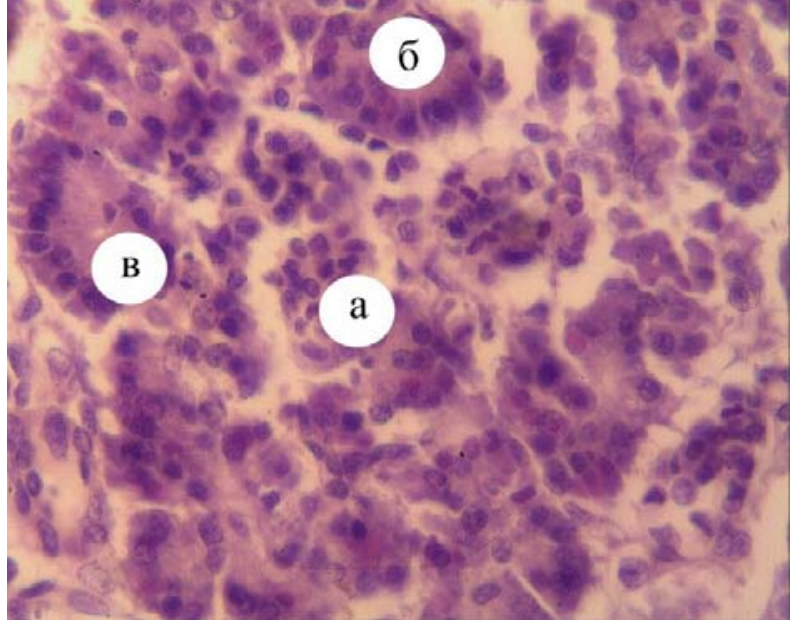

Рис. 1. Фрагмент мікроскопічної будови підшлункової залози клінічно здорового цуценяти однодобового віку: а - острівець Лангерганса; б ацинуси; в - вставний відділ.

Гематоксилін Караці та еозин. $\times 400$.

Органометричними дослідженнями встановлена різниця між величиною часток залози у 14-добовому віці, порівняно $з$ добовим та 7-добовим віком. Так, довжина часток підшлункової залози у собак 14добового віку достовірно $(\mathrm{P}<0,001)$ збільшується у 1,44 раза, порівняно з цуценятами 1-добового віку, та у 1,58 раза, порівняно 3 7-добовими цуценятами i становить $12,62 \pm 0,26$ см. Аналогічні зміни відбуваються відносно ширини лівої, середньої та правої часток. Так, у тварин 14-добового віку показники ширини лівої, середньої правої часток збільшуються, порівняно з 1-добовими цуценятами, відповідно у $1,84,1,16$ та 1,54 раза, порівняно 3 7-добовими - у 2,23, 1,2 та 1,82 раза. Абсолютна та відносна маса підшлункової залози теж зростає і відповідно дорівнює $2,43 \pm 0,09$ г та $0,25 \pm 0,01 \%$.

Морфометричними дослідженнями встановлено зростання площі ендокринної паренхіми підшлункової залози у 1,61 раза, порівняно з 1-добовими цуценятами та 1,58 раза, порівняно 3 цуценятами 7 добового віку, яка становить у цуценят 14-ти добового віку $0,82 \pm 0,06 \%$. Зростання цього показника, на нашу думку, відбувається за рахунок ацинозноінсулярної трансформації, а також внаслідок утворення клітин інсулярного апарату із епітелія дрібних протоків.

Органометричними дослідженнями встановлено, що у собак місячного віку, відносно 14-добових цуценят, абсолютна маса підшлункової залози достовірно $(\mathrm{P}<0,01)$ зростає у 1,45 раза і дорівнює $3,52 \pm 0,31$ г. Відносна маса становить $0,25 \pm 0,03 \%$. Довжина залози також достовірно $(\mathrm{P}<0,01)$ збільшується і дорівнює $16,18 \pm 0,97$ см. Параметри ширини лівої середньої та правої частки органу складають відповідно $1,35 \pm 0,17,1,08 \pm 0,08$ та $0,97 \pm 0,09$ см.

Зовні підшлункова залоза одномісячних цуценят вкрита тонкою сполучнотканинною капсулою, від якої відходять перегородки, що оточують часточки та залозисті структури органу і ділять його на екзокринну та ендокринну частини (рис. 2).

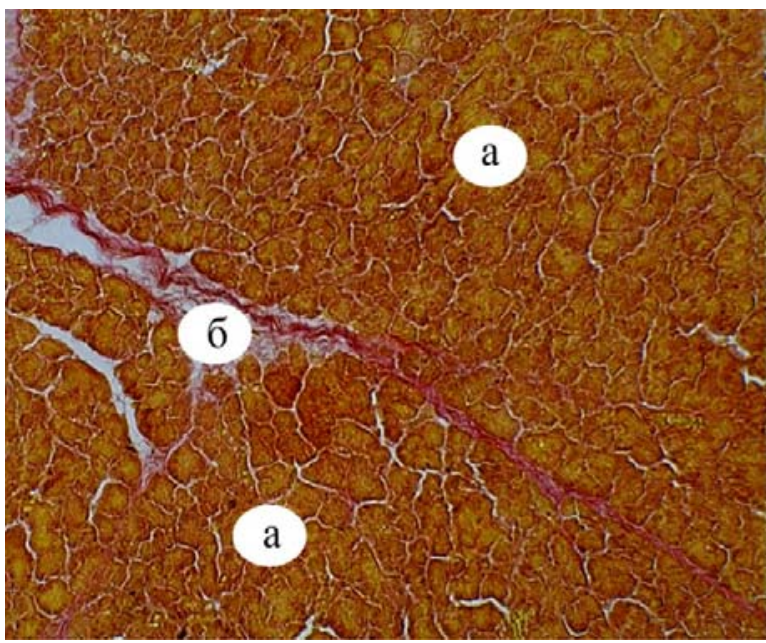

Рис. 2. Мікроскопічна будова підшлункової залози цуценяти одномісячного віку: а - ацинуси; б - колагенові волокна.

Ван-Гізон. $\times 120$.

Об'єм панкреацитів залози одномісячних цуценят, відносно 14-добових, достовірно $(\mathrm{P}<0,01)$ зростає у 1,26 раза і дорівнює $398,43 \pm 20,79$ мкм $^{3}$. Показники об'єму ядра панкреацитів зменшуються і становлять $35,29 \pm 1,77$ мкм $^{3}$. ЯЦВ панкреацитів підшлункової залози у цуценят 1-місячного віку знижуються: порівняно $з$ однодобовими цуценятами у 1,17 раза, порівняно 3 цуценятами 7-добового віку в 1,42 раза та порівняно $з$ 14-добовими цуценятами в 1,5 раза і становлять $0,119 \pm 0,01$ ум. од. Таке зменшення параметрів ядерно-цитоплазматичного відношення, як показали наші морфометричні дослідження, обумовлено інтенсивним ростом цитоплазми панкреацитів, які більш морфофункціонально активні, порівняно 3 такими у попередніх вікових групах.

Площа ендокринної паренхіми 1-місячних цуценят порівняно 3 попередніми віковими групами, зростає i відповідно дорівнює на умовну одиницю площі (ок. 16 , об. 8) $3941,16 \pm 182,62$ мкм² $^{2}$ або $0,87 \pm 0,04 \%$.

Підшлункова залоза цуценят 2-місячного віку різниться органометричними показниками порівняно 3 такими у цуценят місячного віку. Так, абсолютна маса органу достовірно $(\mathrm{P}<0,001)$ зростає і становить $8,2 \pm$ 0,97 г. Довжина органа теж достовірно $(\mathrm{P}<0,05)$ збільшується і дорівнює $23,8 \pm 2,40$ см. Ширина лівої, правої та середньої часток залози складає відповідно $3,05 \pm 0,55,1,38 \pm 0,34$ та $1,82 \pm 0,24$ см. Відносна маса залози цуценят 2-місячного віку становить $0,37 \pm$ $0,06 \%$, що у 1,48 раза більше порівняно 3 цуценятами одномісячного віку.

Площа екзокринної частини підшлункової залози на умовну одиницю (ок. 16 , об. 8) достовірно (Р < $0,001)$ зменшується і становить $445872 \pm 255,88$ мкм $^{2}$ або $98,74 \pm 0,06 \%$. Ендокринна частина паренхіми, навпаки, достовірно $(\mathrm{P}<0,001)$ збільшується та дорівнюе $5712,08 \pm 255,88$ мкм $^{2}$ або $1,26 \pm 0,06 \%$.

Абсолютна маса залози достовірно $(\mathrm{P}<0,001)$ зростає у 3,48 раза, відносно такої у собак 2-місячного віку, і дорівнює $28,5 \pm 1,87$ г. Відносна маса, навпаки, зменшується у 1,16 раза і складає $0,32 \pm 0,03 \%$. Довжина підшлункової залози становить $37,43 \pm 0,76$ см, 
а ширина лівої, середньої, правої часток органу відповідно дорівнює $4,32 \pm 0,62,2,34 \pm 0,18$ та $2,25 \pm$ $0,17 \mathrm{~cm}$.

Екзокринна частина містить ацинуси, між якими $є$ сполучна тканина. Кожен із них має вивідні вставні протоки, які зливаються в більші. Останні в свою чергу впадають у головний вивідний проток підшлункової залози.

Площа, зайнята екзокринною паренхімою у собак 8-місячного віку, відносно такої у тварин попередньої вікової групи, зменшується і становить $98,73 \pm 0,06 \%$, або $445837 \pm 255,87$ мкм $^{2}$ на умовну одиницю площі (ок. 16, об. 8). Ацинуси, діаметр яких у 8-місячних собак складає $36,49 \pm 0,20$ мкм побудовані із 5-12 панкреацитів, що мають овально-трикутну форму 3 широкою основою і звуженою верхівкою.

Абсолютна маса підшлункової залози собак однорічного віку відносно попередньої вікової групи збільшується у 1,19 раза і дорівнює $34 \pm 1,81$ г. Відносна маса залози достовірно (Р < 0,01) зменшується і становить $0,21 \pm 0,01 \%$. Довжина та ширина лівої, середньої та правої часток має тенденцію до збільшення таких показників і дорівнює відповідно $37,55 \pm 1,49$, $3,78 \pm 0,26,2,75 \pm 0,19$ та 2,65 $\pm 0,17$ см.

Площа екзокринної паренхіми підшлункової залози достовірно $(\mathrm{P}<0,05)$ зменшується відносно попередньої вікової групи і становить $444848 \pm 235,1$ мкм $^{2}$ або 98,51 \pm 0,05\% на умовну одиницю площі (ок. 16, об. 8). Ендокринна частина, навпаки, достовірно $(\mathrm{P}<0,05)$ збільшується та дорівнює 6736,43 \pm 235,1 мкм $^{2}$, або $1,49 \pm 0,05 \%$.

Ацинуси мають огруглу, овальну та видовжену форми та займають основну частину паренхіми органа. Діаметр ацинусів собак 12-місячного віку становить 35,94 \pm 0,39 мкм. Об'єм панкреацитів та їх ядер у тварин даної вікової групи, відносно попередньої, знижується у 1,13 і 1,1 раза відповідно та дорівнює $507,23 \pm 13,94$ та $35,50 \pm 2,20$ мкм $^{3}$. Показник ядерноцитоплазматичного відношення панкреацитів не змінюються і складає 0,092 \pm 0,01 ум.од.

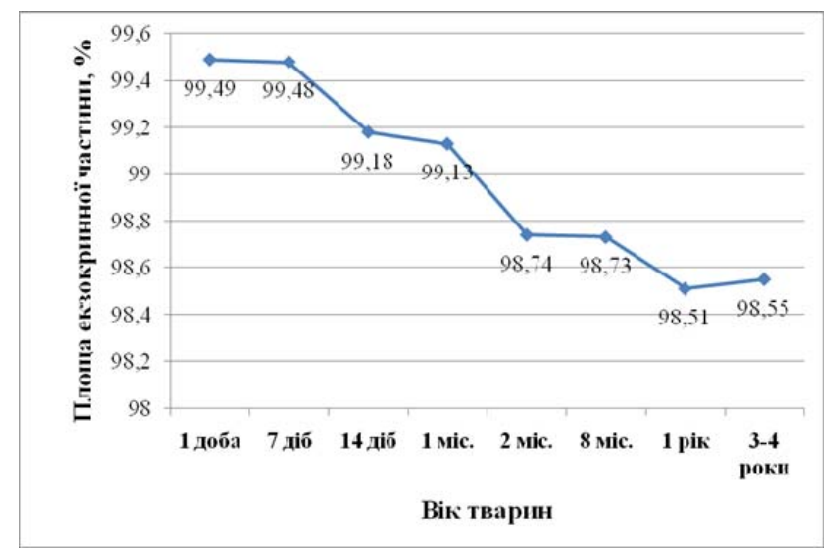

Рис. 3. Морфометричні показники площі екзокринної частини підшлункової залози собак у постнатальному періоді онтогенезу

Абсолютна та відносна маса підшлункової залози 3-4-річних собак, порівняно з собаками однорічного віку, зменшується у 1,14 і 1,31 раза і відповідно ста- новить $29,83 \pm 3,0$ г та $0,16 \pm 0,03 \%$. Довжина та ширина лівої, середньої, правої часток підшлункової залози статевозрілих собак відповідно дорівнює $29,8 \pm 2,05,3,63 \pm 0,22,2,83 \pm 0,23$ і $2,63 \pm 0,22$ см.

Гістоархітектоніка підшлункової залози сформована 3 окремих часточок. Основну їх масу складає екзокринна паренхіма, решта припадає на ендокринну. Площа екзокринної частини органу собак 34-річного віку складає $445021 \pm 311,82$ мкм $^{2}$ або $98,55 \pm 0,07 \%$ (рис. 3). Ендокринна частина підшлункової залози відповідно становить 6562,81 311,82 мкм $^{2}$ та $1,45 \pm 0,07 \%$ на умовну одиницю площі (ок. 16, об. 8).

Ацинуси мають переважно округлу та продовгувату форму. Їх діаметр у собак 3-4-річного віку становить $36,65 \pm 0,13$ мкм. Об'єм панкреацитів та їх ядер відповідно дорівнює 507,84 $\pm 25,06$ і 33,22 $\pm 1,67$ мкм $^{3}$. Ядерно-цитоплазматичне відношення панкреацитів становить $0,089 \pm 0,01$ ум. од. У тварин попередньої вікової групи такий показник дорівнює $0,092 \pm 0,01$ ум. од.

\section{Висновки}

Гістоструктура підшлункової залози собак в постнатальному періоді онтогенезу має подібну будову, проте різниться органометричними показниками:

-показники відносної маси органу після народження цуценят до 2-місячного віку зменшується, після 2місячного віку вони дещо зростають, а $з$ настанням статевої зрілості починають знову зменшуватись;

-у собак 8-місячного віку порівняно з одно- та 2місячним віком спостерігається достовірне зростання довжини і ширини лівої, середньої та правої часток підшлункової залози;

-у одно- та 3-4-річному віці собак у порівнянні 3 попередніми віковими групами тварин відбувається зменшення довжини та ширини лівої частки органу, проте аналогічні показники середньої та правої частки підшлункової залози зростають.

Екзокринна частина займає основну масу паренхіми органа - площа їі у новонароджених цуценят складає 99,49 $\pm 0,04 \%$. 3 віком вміст екзокринної паренхіми зменшується і у статевозрілих собак віком 34 роки дорівнює $98,55 \pm 0,07 \%$. Ендокринна частина підшлункової залози у постнатальному періоді онтогенезу зростає.

Перспективи подальших досліджень передбачають, по-перше, провести гістохімічні дослідження підшлункової залози собак у віковому аспекті. Подруге, напрямок досліджень повинен бути спр на проведення ультраструктурної будови підшлункової залози у досліджуваних тварин.

\section{Бібліографічні посилання}

Akhtemiichuk, Yu.T., Slobodian, O.M. (2006). Makrobudova pidshlunkovoi zalozy na rannikh etapakh ontohenezu liudyny. Bukovynskyi medychnyi visnyk. 10(3), 133 (in Ukrainian).

Horalskyi, L.P., Dubych, I.M. (2010). Orhanometrychni pokaznyky pidshlunkovoi zalozy sobak u postnatalnomu periodi ontohenezu. mat. nauk.-prak. 
konhresu [IV mizhnarodni Pyrohovski chytannia]. (Vinnytsia, 2-5 chervnia 2010 r.). Vinnytskyi natsionalnyi medychnyi universytet im. Pyrohova Vinnytsia, 25-26 (in Ukrainian).

Horalskyi, L.P., Khomych, V.T., Kononskyi, O.I. (2012). Osnovy histolohichnoi tekhniky i morfofunktsionalni metody doslidzhennia $u$ normi ta pry patolohii: [navchalnyi posibnyk]. Zhytomyr: Polissia (in Ukrainian).
Slobodian, O.M. (2008). Intehrovane morfometrychne doslidzhennia pidshlunkovoi zalozy $\mathrm{v}$ perynatalnomu periodi ontohenezu. Tavrycheskyi medykobyolohycheskyivesnyk. 11(3), II, 134-138 (in Ukrainian).

Holzknecht, N., Gager, J., Helmberger, T. (1996). Techniques and application of MR-pancreatography compared to endoscopic retrograde pancretography. Radiol. 36(5), 427-434.

Стаття надійшла до редакиії 27.03.2017 